Note: This is a pre-copy-editing, author-produced PDF of an article accepted for publication in Substance Use \& Misuse following peer review. The definitive publisher-authenticated version [McKinney A and Coyle K (2005) Research note: Patterns of Alcohol Consumption in a Northern Irish Sample, Substance Use \& Misuse, 40(4):573-579] is available online at http://www.informaworld.com/smpp/title $\sim \mathrm{db}=$ all content=g716078969

\title{
Research Note: Patterns of Alcohol Consumption in a Northern Irish Sample
}

\author{
ADELE McKINNEY ${ }_{1}$ AND KIERAN COYLE2 \\ 1University of Ulster, Department of Mental Health, Whital Medical Building, City Hospital, Belfast, \\ Northern Ireland \\ 2University of Ulster, University of Ulster at Magee, Northland Road, Derry, Northern Ireland
}

Published in Substance Use \& Misuse (2005), 40(4):573-579

Copyright: Taylor \& Francis

This paper examines the drinking habits of a Northern Irish sample during a six-month period in 1998. In addition the study examines the influence of contextual variables on the quantity and frequency of alcohol consumption. Questionnaires were administered to 600 participants; the response rate was $39.8 \%$ (239). An unexpected low abstinence rate was observed that, however, may be due to response bias. The results revealed high frequency (29.7\% drink on four or more days a week) and high quantity of alcohol consumption (mean units per week 43.21, SD 40.33). Beer drinkers consumed the largest quantity of alcohol and also had the highest frequency of alcohol consumption. It was observed that $45.8 \%$ of all drinking events took place in a public bar and the popularity of the public bar for alcohol consumption was not influenced by age or gender. The present investigation revealed that almost half (45\%) of individuals consume more than one type of beverage at one sitting, and there is a trend of consuming alcohol in more than one place during a single drinking session. These results indicate a distinctive drinking pattern within Northern Ireland and have implications for studies investigating the effects of alcohol on the social drinker.

Keywords binge drinking; alcohol consumption; drinking pattern; abstinence rate; Northern Ireland

\section{Introduction}

Drinking habits in Northern Ireland can be distinguished from drinking habits in the wider European and United Kingdom contexts. In Europe it is common for people to consume small amounts of alcohol frequently. In contrast, Northern Ireland is associated with a more concentrated drinking style. Northern Ireland has long had a large proportion of total abstainers (Blaney and MacKenzie, 1978; Sweeny et al., 1990), with $30 \%$ of adults who do not drink at all. However, within its population of drinkers, drinking tends to be less frequent with greater quantities (Blaney and MacKenzie, 1978; Sweeny et al., 1990; Harbison and Haire, 1982). There is also evidence to suggest that the number of women who drink is increasing, and that drinking is heaviest among younger age groups (Harbison and Haire, 1982).

A focus of large-scale research has been placed on the examination of drinking practices in terms of user characteristics. Drinking practices have been found to vary according to age, sex, socio-economic status, income, education, ethnicity, religious affiliation, marital status, and urbanization (Calahan et al., 1969; Casswell, 1980; Dight, 1976). Recently attention has been directed toward the study of influential factors other than the characteristics of individuals. Situational and contextual variables differ according to demographic variables and have been found to be important determinants of alcohol consumption (Clark, 1977; Harford, 1983). It has been observed that in Great Britain, drinking in a home setting is the most popular location for women, while bars are a more common setting for men (Dight, 1976; Wilson, 1980).

The present research aims to investigate the alcohol consumption patterns of a Northern Irish sample. It is predicted that large quantities of alcohol will be consumed during one sitting. The present study also aims to investigate the association between the place of alcohol consumption and the quantity and type of alcohol consumed in terms of user characteristics, gender, age, and occupation.

\section{Method}

Data collection began in May 1998 and was completed October 1998. 


\section{Participants}

Sixty first-year psychology students within the University of Ulster distributed 10 questionnaires outside the college environment. The participants were informed that the study was concerned with the assessment of normal drinking practices within the population. Respondents were not required to give their name but could do so if they were willing to take part in further studies. Of the total number of questionnaires distributed, 239 were returned, 108 (45.2\%) from males and 131 (54.8\%) from females. Only 36 forms included the individual's name and contact details.

\section{Materials}

The study employed a short self-report questionnaire (after Knight and Longmore, 1994, p.97). Respondents were asked to report their gender, date of birth and occupation. Frequency of drinking, using the previous month as a reference, was assessed using a five-point scale. The five-point scale ranged from consuming alcohol no days in the previous month to six to seven days per week. This information was obtained for each type of beverage: beer, wine, and spirits. Respondents also provided information concerning the amount of each alcoholic beverage consumed at one sitting, this ranged from no pints of beer to eight or more pints, no glasses of wine to 15 or more, and no measures of spirits to 15 or more. The question concerning place of alcohol consumption provided four choices in which alcohol is usually consumed; pub or bar, at home or the home of friends or relatives, a club or disco, or somewhere else. Using the last week as a reference, respondents reported on which day(s) of the week they had consumed alcohol.

\section{Results}

Two hundred thirty nine (39.8\%) of the questionnaires were returned. The results reveal that $8 \%$ of the respondents were abstainers. Among the alcohol consumers Friday (59\%) and Saturday $(73.6 \%)$ are the most popular days for alcohol consumption. A total of 591 drinking events were reported for the total sample within the previous month. As can be seen from Table 1,53.63\% of all drinking events occur on the weekend.

It was observed that the public bar (68.8\% of respondents) is the most popular place for consuming alcohol, accounting for almost half (45.8\%) of all drinking events. As can be seen from Table 2 , the respondents who drink beer have the highest frequency, $23.4 \%$ of the respondents drink beer six to seven times a week, and the highest volume, $31.8 \%$ consume $>14$ units per occasion. It was revealed that almost half the sample mixes their drinks $(45 \%)$, that is the consumption of beer and spirits on any one occasion (see Table 3). The age distribution of the sample was: $20 \%$ of participants under 20 years, $42.3 \%$ aged between $20-30,23 \%$ aged between $30-40,10.9 \%$ aged $40-50$, and $3.8 \%$ aged over 50 years. The mean age of respondents was 30.01 (SD 10.233) with a median age of 28. A median split was employed to look at the effects of age on consumption (28 years and under 125 respondents, over 28 years 114 respondents).

\section{Table 1}

Number and percentage of respondents who consume alcohol each day of the week

\begin{tabular}{lcc}
\hline Day & $\begin{array}{c}\text { Number (\%) of people who } \\
\text { drink on each day }\end{array}$ & $\begin{array}{c}\text { \% of all drinking events for each } \\
\text { day of the week }\end{array}$ \\
\hline Monday & $46(19.2)$ & 7.78 \\
Tuesday & $62(25.9)$ & 10.49 \\
Wednesday & $36(15.1)$ & 6.09 \\
Thursday & $67(28.0)$ & 11.36 \\
Friday & $141(59.0)$ & 23.85 \\
Saturday & $176(73.6)$ & 29.78 \\
Sunday & $63(26.4)$ & 10.65 \\
\hline
\end{tabular}


Table 2 The number (\%) of respondents who consume each type of beverage 0-7 days per week and the number (\%) of respondents who consume each quantity of each type of beverage per drinking occasion

\begin{tabular}{lccccc}
\hline & \multicolumn{5}{c}{ Number days each type of beverage was consumed } \\
\cline { 2 - 5 } & No days & $\mathrm{N}(\%)$ & $\mathrm{N}(\%)$ & $\mathrm{N}(\%)$ & $\mathrm{N}(\%)$ \\
& $\mathrm{N}(\%)$ & 1 & $2-3$ & $4-5$ & $6-7$ \\
\hline Beer & $78(32.6)$ & $21(8.8)$ & $57(23.8)$ & $27(11.3)$ & $56(23.4)$ \\
Wine & $153(64)$ & $40(16.7)$ & $29(12.1)$ & $9(3.8)$ & $8(3.3)$ \\
Spirits & $134(56.1)$ & $21(8.8)$ & $45(18.8)$ & $19(7.9)$ & $19(7.9)$ \\
& \multicolumn{5}{c}{ Volume of each beverage consumed at one sitting } \\
\hline Beer & $0 \mathrm{~N}(\%)$ & $2 \mathrm{~N}(\%)$ & $4 \mathrm{~N}(\%)$ & $6 \mathrm{~N}(\%)$ & $\geq 7 \mathrm{~N}(\%)$ \\
Wine & $15(33.9)$ & $18(7.5)$ & $35(14.6)$ & $29(12.1)$ & $76(31.8)$ \\
Spirits & $153(64)$ & $24(10)$ & $26(10.9)$ & $18(7.5)$ & $14(5.9)$ \\
\hline
\end{tabular}

\section{Table 3}

The number and percentage of participants who reported consuming each combination of mixed drinks on any drinking occasion

\begin{tabular}{lll}
\hline & N & $\%$ \\
\hline Beer & 74 & 31 \\
Wine & 26 & 10.9 \\
Spirits & 21 & 8.8 \\
Beer and Wine & 16 & 6.7 \\
Beer and Spirits & 40 & 16.7 \\
Wine and Spirits & 14 & 5.9 \\
Beer, Wine and Spirits & 29 & 12.1 \\
\hline
\end{tabular}

Pearson Chi-square statistics were employed to investigate the effect of age on place of alcohol consumption and the younger and older age groups. These analyses revealed that age group was related to the consumption of alcohol in a club or disco [Pearson $\left.x^{2}(1, \mathrm{~N}=239)=35.307, p<0.001\right]$ ] $(53.6 \%$ of younger, $16.7 \%$ of older respondents). No other relationships reached significance. The quantity of each type of beverage was converted into units and independent samples, $t$-tests were employed to investigate the effects of age group on the quantity of each type of beverage consumed per drinking occasion. These analyses revealed significantly [t $(237)=3.55, p<0.01]$ more spirits consumed per occasion by the younger age group (mean 7.376, SD 9.3115) compared to the older age group (mean 3.5526, SD 7.0637).

It was revealed that men consumed significantly [t $(237)=9.689, p<0.001$ ] more beer, than did women (female mean 4.32, SD 5.4; male mean 11.28, SD 5.62) per drinking occasion. And women consumed significantly [t $(233)=-4.071, p<0.001]$ more wine than did men (female 2.22, SD 3.10, male 0.7824 SD, $2.17)$ per drinking occasion. No difference in the volume of spirits was observed [t $(237)=0.833, p>$ 0.05].

\section{Discussion and Conclusions}

The present investigation failed to confirm the high abstinence rate, within Northern Ireland, of $30 \%$ (DHSS, 1999). The low abstinence rate, $8 \%$, observed in the present investigation may represent a selfselection bias, in that individuals who do not drink did not take part. The methodology employed in the DHSS (1999) study comprised of an interview, thus facilitating the necessary recording of responses from non-drinkers. The present investigation revealed that weekend drinking is more popular than is weekday drinking. The Northern Ireland Drink Survey (1999) revealed a range of 13\%-16\% of respondents who consume alcohol on any weekday. The present investigation revealed a range of $15 \%-28 \%$ of the sample who reported drinking alcohol on any day during the week. In contrast to the Northern Ireland Drink Survey (1999), observation that $34 \%$ and54\%of respondents consume alcohol on a Friday and Saturday night, respectively, the present investigation revealed that $59 \%$ have a drink on a Friday night and $73.6 \%$ have a drink on a Saturday night. Thus, the results from the present investigation would suggest more frequent drinking. The present study is limited in the small response rate, and the lack of information on the characteristics of non-respondents. However it does support the previous evidence that was observed in the broader community. The DHSS survey of Northern Ireland (1999) revealed that $39 \%$ of drinkers binged (more than 10 units). In the current study $60 \%$ of the present sample consumed more than 10 units at any one sitting, thus confirming the high quantity in conjunction with the high frequency of alcohol 
consumption of the present sample. The present investigation revealed that the public bar is the most popular place of alcohol consumption (45.8\%); neither gender nor age of the participants influences the popularity of the public bar. The highest frequency and quantity of alcohol consumption was observed for respondent's who reported drinking beer. It was revealed that $67.4 \%$ of respondents drank beer, and of these respondents, $34.7 \%$ drank six or seven days a week. This is in contrast to a national $8 \%$ daily alcohol intake (DHSS, 1999). In conjunction with the prevalence of high frequency of beer consumption was the reported large quantity of beer consumed. The most frequently reported quantity of beer, 16 units per occasion, was twice that of the most frequently reported quantity of spirits and more than four times the most frequently reported quantity of wine. This result offers support to the findings that beer drinkers observed in a natural setting consumed about three times as much as spirit drinkers Stockwell et al., 1992). The present study also supports the findings that males consume more beer than do females. The findings of the present investigation confirm the previously observed prevalence of binge drinking in Northern Ireland. This suggests that a high level of alcohol consumption at one sitting is the accepted and, possibly, the expected norm of drinking. The present research also indicates that individuals consume more than one type of beverage on any one drinking occasion. It was also observed that people consume alcohol in more than one place throughout an evening of alcohol consumption. That is, they may have a drink in a friends house before going to a bar and later proceeding to a night-club. This variation in beverage choice and place of consumption has implications for research on the effects of alcohol on the social drinker. It is common in past research on the effects of alcohol on the social drinker to administer a standard drink, usually vodka in a laboratory setting.

Consequently the effects of alcohol consumption related to real life situations is not being addressed either in relation to quantity and type of beverage nor in relation to the drinking environment. The present study revealed that the public bar is the most popular place for alcohol consumption. This represents an environment laden with social meaning thus, making replication in a laboratory very difficult. These aspects of alcohol consumption by the social drinker are currently under investigation and the effects, specifically on cognitive function, will form the basis of future reports.

There is a tendency for binge drinking in Northern Ireland. It provides evidence that there is a tendency for individuals to mix drinks and also to drink in different venues on the same drinking occasions.

\section{THE AUTHORS}

Dr Adele McKinney. Areas of interest are the next day effects of a normal night's drinking on mood and cognition, also interested in the impact of life events precipitating a first episode of psychosis.

Dr Kieran Coyle. Areas of interest the effects of sleep deprivation on cognition.

\section{References}

Blaney, R., MacKenzie, G. (1978). Department of Community Medicine, Queen's University, Belfast. A Northern Ireland Community Health Study DHSS.

Sweeny, K., Gillian, J., Orr, J. (1990). Drinking habits in Northern Ireland, 1987-1989.Policy Planning and Research Unit Occasional Paper 22, DHSS.

Harbison, J. J. M., Haire, T. (1982). Drinking practices in Northern Ireland. Policy Planning and Research Unit, Department of Finance and Personnel.

Cahalan, D., Cisin, I., Crossley, H. (1969). American drinking practices: A national study of drinking behaviour and attitudes. Monograph No. 6, Rutgers Center of Alcohol Studies, New Brunswick, New Jersey.

Casswell, S. (1980). Drinking by New Zealanders. Auckland, New Zealand: Alcoholic Liquor Advisory Council, Wellington, and the Alcohol Research Unit.

Dight, S. E. (1976). Scottish drinking habits: A survey of Scottish drinking habits and attitudes toward alcohol carried out in 1972 for the Scottish Home Health Department. London: HMSO.

Clark,W. B. (1977). Contextual and Situational Variables in Drinking Behavior, Berkeley: University of California, Social Research Group.

Harford, T. C. (1983). A contextual analysis drinking events. International Journal of Addiction. 18:825834.

Wilson, P. (1980). Drinking in England andWales: An enquiry carried out on behalf of the Department of Health and Social Security, London HMSO.

Knight, R. G., Longmore, B. E. (1994). Clinical Neuropsychology of Alcoholism. East Sussex, UK: Erlbaum.

Stockwell, T., Rydon, P., Gianatti, S., Jenkins, E., Ovenden, C. Syed, D. (1992). Levels of drunkenness of customers leaving licensed premises in Perth, Western Australia: A comparison of high and low risk premises. Brit J. Addict 87:873-881. 


\section{Modèles de la Consommation d'alcool Parmi un Échantillon d'Irlandais du Nord}

\section{RÉSUMÉ}

Cet article examine la consommation d'alcool d'un échantillon d'irlandais du Nord pendant une période de 6 mois, en 1998. En outré, l'etude examine l'influence des variables

contextuelles par rapport `a la quantité et `a la fréquence de consommation d'alcool. Des

questionnaires ont été administrés `a 600 participants, le taux de réponse était de $39.8 \%(239)$. On a observé un taux d'abstinence inattendu qui peut être dû `a des réponses distordues. Les résultats ont indiqué une consommation d'alcool hautre en fréquence (29.7\% boirent 4 jours ou plus par semaine) et en quantité (unit'es moyennes consommés par semaine 43.21, écart-type 40.33). Les buveurs de bière ont consommé la plus grande quantité d'alcool et ont également eu la fréquence de l'consommation d'alcool la plus élevée. On a observé que $45.8 \%$ de la totalité de la consommation d'alcool a eu lieu dans un bar (établissement publique) et que le choix de ce genre d'etablissement pour consumer de l'alcool n'était ni influence par l'age oule sexe. La' recherche actuelle a indiqué que prés de la moitié $(45 \%)$ des individus interrogés ont tendance `a consommer plus qu'une seule sort'e de boisson `a un endroit donné et qu'il y a une tendance 'a consommer de l'alcool dans plus d'un établissement lors d'une seule beuverie. Ces résultats indiquent qu'il existe un modèle de consommation d'alcool caractéristique ‘a l'Irlande du Nord qui a des conséquences sur des études examinant les effets de l'alcool sur les individus buvant de l'alcool en société occasionnel.

\section{Patrones en el Conssumo del Alcohol de Una Muestra de Irlanda del Norte}

\section{RESUMEN}

Est articulo examina los h'abitos en el consumo de alcohol de una muestra norirlandesa durante un per'ıodo de 6 meses en 1998. Adem'as el estudio examina la influencia de variables contextuales en la cantidad y frecuencia del consumo de alcohol. Los cuestionarios se dministraron a 600 participantes, la tasa de respuesta era de $39.8 \%$ (239). Se observo un inesperado bajo porcentaje en abstinencia. Sin embargo esto puede ser debido a una respuesta influenciada. Los resulados revelaron consumo de alcohol con una gran frecuencia ( $29.7 \%$ beben entre 4 o m 'as dias semanalmente) y en elevadas cantidades (43.1 unidades semanalmente, SD 40.33). Bedebores de cerveza consumieron la mayor cantidad de alcohol as'i como con la mayor frecuencia. Sa observ'o que $45.8 \%$ de los actos socials incluyendo el consumo de alcohol se llevaron a cabo en establecimientos cuya fama no estaba eterminada por el g'enero o edad del p'ublico. La actual investigaci'on revela que casi la mitad de los individuos (45\%) consumen m 'as de un tipo de bebida en el mismo lugar y existe una tendencia a consumir alcohol en m`as de un establecimiento durante una unica session. Estos resultados indican un modelo caracteristico dentro de Irlanda del Norte lo que conlleva implicaciones para los estudios que investigan los efectos del alcohol en la persona que bebe socialmente. 